\title{
Performance Comparison Modeling Between Single-phase Cycloconverters and Three-phase Cycloconverters Using Matlab Simulink Tools
}

\author{
Setiyono, Bambang Dwinanto \\ Universitas Gunadarma, Jalan Margonda Raya 100, Depok 16424, Indonesia
}

\begin{tabular}{|c|c|}
\hline ARTICLE INFO & ABSTRACT \\
\hline Article history: & \multirow{15}{*}{$\begin{array}{l}\text { This paper presents a performance comparison of a single-phase AC } \\
\text { to AC converter (cycloconverter) and a three-phase converter circuit } \\
\text { which divides the input wave frequency (fin) into a variable frequency } \\
\text { with the frequency value of the AC output voltage waveform } \\
\text { (alternating current) (f, fin/2, fin/3, fin/ } 4 \text {, fin } / 5 \text {, fin } / 6 \text {, fin } / 7 \text {, fin } / 8 \text {, fin } / 9 \text {, } \\
\text { fin/10. Cycloconvertor switches are built using a diode and a thyristor } \\
\text { device. This research was conducted by modeling each cycloconverter } \\
\text { circuit using Matlab Simulink tools. Modeling simulation parameters } \\
\text { to be analyzed include the output waveform RMS (root mean square) } \\
\text { value, frequency value, and Total Harmonic Distortion (THD) index } \\
\text { for each wave. The output frequency voltage waveform of } \\
\text { cycloconverter is affected by the variation of the trigger signal of the } \\
\text { P-side (positive) converter and the N (negative) converter side switch. } \\
\text { Simulation results show that adjusting the firing pulse width of the } \mathrm{P} \\
\text { converter and the N converter will produce an output voltage wave that } \\
\text { has an index value of THD, Vrms, and form factor for each diode and } \\
\text { thyristor cycloconverter circuit. }\end{array}$} \\
\hline Received March 03, 2021 & \\
\hline Revised June 08, 2021 & \\
\hline Accepted July 09, 2021 & \\
\hline Keywords: & \\
\hline Cycloconverter; & \\
\hline $\begin{array}{l}\text { Variable Frequency; } \\
\text { RMS; }\end{array}$ & \\
\hline THD & \\
\hline & \\
\hline & \\
\hline & \\
\hline & \\
\hline & \\
\hline & \\
\hline & \\
\hline
\end{tabular}

This work is licensed under a Creative Commons Attribution-Share Alike 4.0

Setiyono

Universitas Gunadarma, Jalan Margonda Raya 100, Depok 16424, Indonesia

Email: setiyono@staff.gunadarma.ac.id

\section{INTRODUCTION}

Power plants generally supply voltage or electric current to loads with fixed voltage and frequency values. However, certain loads require a voltage source with varying frequencies. For example, washing machines, vacuum cleaners, water pumps, and induction motors that are widely used in industry, the rotational speed performance of these equipment requires a variation of the input voltage with changing frequency $[1][2][3][4][5][6][7][8][9][10][11][12]$. Cycloconvertor is one of the right solutions as a power supply with an adjustable output voltage frequency and generally a frequency lower than the input frequency without DC current regulation. Cyclo-converters require a high-power switching mechanism which is generally carried out by semiconductor devices including thyristors, SCRs, MOSFETs, and TRIACs to obtain variable frequency output waveform settings. Until now, the development of the cycloconverter is still ongoing, and several researchers have made various discoveries.

Kshitij Kumar developed a cycloconverter circuit that is applied to induction motor drives. The cycloconvertor switch is built using an SCR (Silicon Controlled Rectifier) and is controlled by an 8051 microcontroller with an Opto-isolator light sensor (MOC 3021) to isolate the high frequency modulated driver control circuit with a low-frequency cycloconverter circuit. The result is a cycloconverter that is built to be able to provide a choice of speed settings at the output voltage frequencies $f, f / 2$, and $f / 3$ from the input frequency [1]. Nyein built a cycloconverter circuit for induction motor drives where the cycloconverter switch 
uses a Triac device. The pulse switch controller uses a PIC18F4550 microcontroller. The result is, the frequency setting can be set in five steps $f, f / 2, f / 3, f / 4$ and $f / 5$. So that the output voltage frequency value is lower than the input voltage frequency [2]. Patel made a single phase step-down cycloconverter circuit using an SCR device with Arduino microcontroller control. The result is a cycloconverter set in the operating area of the $f, f / 2$ and $f / 3$ frequency settings [3]. Pandey, in his research entitled modeling, single-phase cycloconverter. He simulates a single-phase step-down cyclo converter modeling without changing the DC direct current value on the output voltage side [4].

This paper aims to describe the performance comparison of single-phase and three-phase cycloconverters using semiconductor devices, diodes and thyristors through modeling simulations. Compared to previous researchers, this study also intends to develop a cycloconverter circuit that has a wider choice of frequency settings, namely $f, f / 2, f / 3, f / 4, f / 5, f / 6, f / 7, f / 8, f / 9$ and $f / 10$. Modeling is done using the Simulink Matlab tools. The contribution of this research is to provide technical contributions in the field of power electronics, especially in the design of a mesh frequency divider product with a wider output frequency setting.

\subsection{Single Phase Cycloconverter}

Fig. 1 is single Phase Cycloconverter arranged using 8 thyristor semiconductor switches (P1 to P4 and $\mathrm{N} 1$ to N4). Four left side switches on the strand become a series of $\mathrm{P}$ (positive) converters, and four right side thyristor switches are built as negative $(\mathrm{N})$ converters. These two converters are operated as full-wave bridge rectifiers. This converter works alternately when one converter is turned on. Then the other converter is turned off. Adjustment of firing angle of each switch results in the same output voltage of the converter $\mathrm{P}$ and the converter $\mathrm{N}$ but has a phase difference of $180^{\circ}$. If converter $\mathrm{P}$ is active, the average output voltage is positive $\left(\mathrm{V}_{0}\right)$; likewise, if converter $\mathrm{N}$ is active, the output voltage is negative $\left(-\mathrm{V}_{0}\right)$. If a positive converter works at a time $\frac{T_{0}}{2}$ and the negative converter works at a time $\frac{T_{0}}{2}$, the output voltage frequency will be obtained at $f_{0}=\frac{1}{T_{0}}$. The output voltage and frequency are determined by firing pulses connected by gate legs P1 to P4 and N1 to N4.

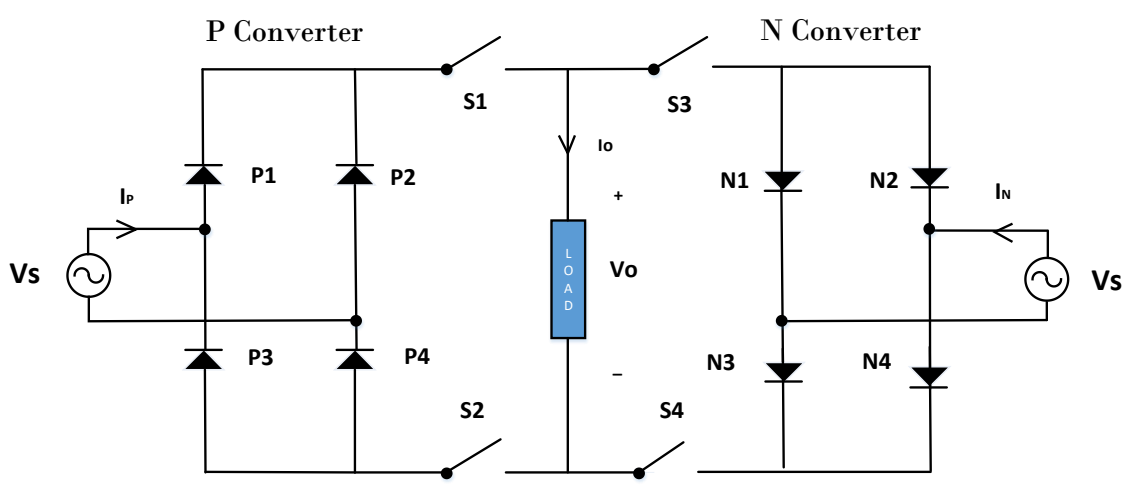

Fig. 1. Single-Phase Diode Cycloconverter

The firing pulses of S1 and S2 are identical or the same, while firing pulses of S3 and S4 are a negation of $\mathrm{S} 1$ and S2. The source voltage is an alternating voltage with a frequency of $50 \mathrm{~Hz}$ with a magnitude of 100 volts peak to peak. Parameters of output voltage $\mathrm{V}_{0}$, RMS, and THD values are highly dependent on pulses of the $\mathrm{P}$ converter and $\mathrm{N}$ converter. If $\alpha_{\mathrm{P}}$ is a positive delay angle, then delay angle for the negative converter is $\alpha_{\mathrm{N}}=\pi-\alpha_{\mathrm{P}}$. The average output voltage of the positive converter $(\mathrm{P})$ is the same and is opposite to the negative converter (N) [14][15].

$$
\begin{gathered}
V_{0 P}=-V_{0 N} \\
V_{0}=V_{s}\left[\frac{1}{\pi}\left(\pi-\alpha+\frac{\sin 2 \alpha}{2}\right)\right]^{\frac{1}{2}}
\end{gathered}
$$

The average output voltage for positive $1 / 2$ cycle is

$$
\begin{gathered}
V_{d c}=\frac{2}{2 \pi} \int_{\alpha}^{\pi+\alpha} V_{m} \sin \omega t d(\omega t)=\frac{2 V_{m}}{2 \pi}(-\cos \omega t)_{\alpha}^{\pi+\alpha} \\
V_{d c}=\frac{2 V_{m}}{\pi} \cos \alpha
\end{gathered}
$$

Performance Comparison Modeling Between Single-phase Cycloconverters and Three-phase Cycloconverters Using Matlab Simulink Tools (Setiyono) 
The output voltage RMS value is given as

$$
\begin{gathered}
V_{r m s}=\left[\frac{2}{2 \pi} \int_{\alpha}^{\pi+\alpha} V_{m}^{2} \sin ^{2} \omega t d(\omega t)\right]^{\frac{1}{2}} \\
V_{r m s}=\frac{V_{m}}{\sqrt{2}}
\end{gathered}
$$

But the instantaneous value of the two output voltages can be different [5].

Fig. 2(a) is a sinusoidal input voltage waveform with a frequency of $50 \mathrm{~Hz}$. Fig. 2(b) is the output voltage waveform dividing three frequency input voltage waves at the firing angle $\alpha_{P}=0^{0}$ and $\alpha_{N}=\pi$. The first three positive cycles are directed by $\mathrm{P}$ converter, and the first three negative cycles are aligned by the $\mathrm{N}$ converter. The output wave frequency is represented by a red line wave of $16.67 \mathrm{~Hz}$. Whereas in Fig. 2(c) is the cycloconverter waveform when turned on at a firing angle $\alpha_{P}=45^{\circ}$ and $\alpha_{N}=\pi+45^{0}$. It appears that firing angle is very influential on the output voltage waveform, RMS, and THD values generated.

(a)

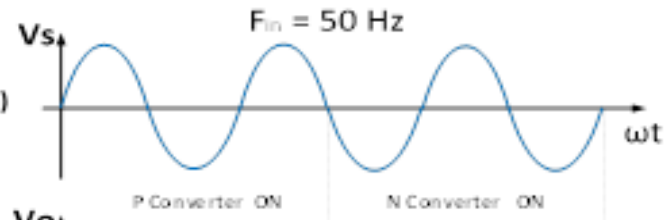

(b)

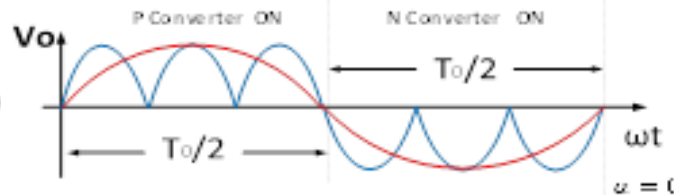

(c)

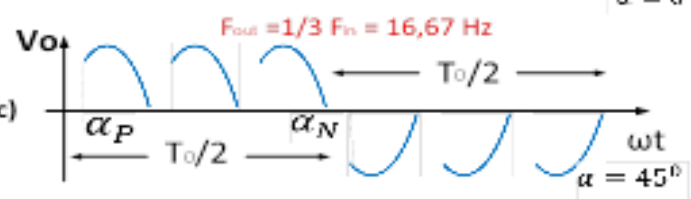

Fig. 2. Three-Frequency Input Voltage Divider Waveform

\subsection{Three Phase Cycloconverter}

The concept of a three-phase cycloconverter is the same as a single-phase cycloconverter. This circuit requires three different voltage sources of $120^{\circ}$ phases with the same wave frequency for each phase. The arrangement of the converter consists of six switches on the P converter and six switches on the $\mathrm{N}$ converter. Fig. 3 is a three-phase cycloconverter circuit using 12 thyristors.

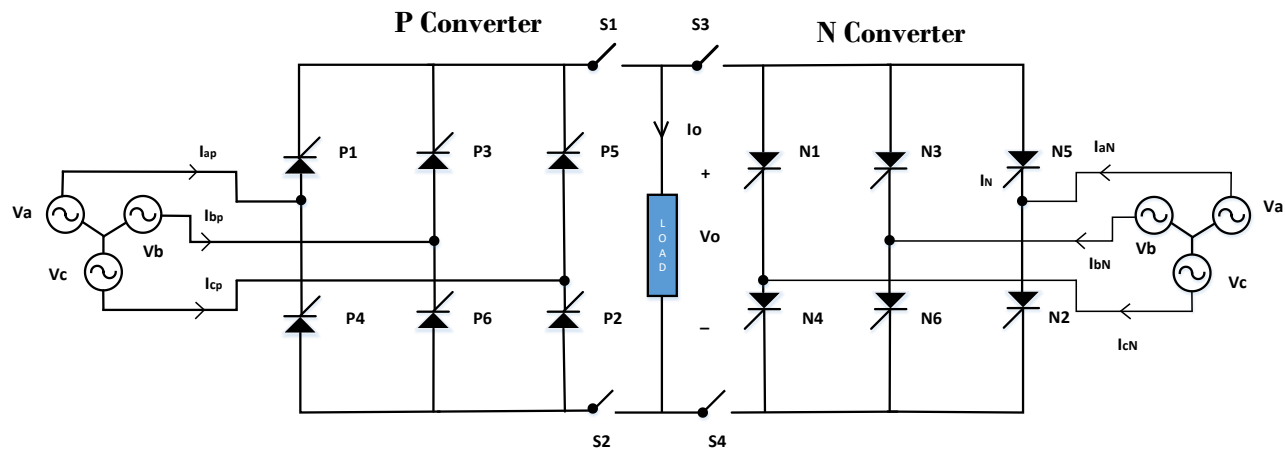

Fig. 3. Three-Phase Thyristor Cycloconvertor

Switches P1 to P6 are converter P (positive), and switches N1 to N6 are N (negative) converters. The output voltage $\mathrm{V}_{0}$ is generated by the performance of positive converter $(\mathrm{P})$ and negative $(\mathrm{N})$ converter switches working alternately. Both of these converters can operate in four quadrants $(+\mathrm{V},+\mathrm{I},-\mathrm{V},-\mathrm{I})$ or in two modes (Inverting and Rectifying). In Quadrant $+\mathrm{V},+\mathrm{I}$ in rectifying mode, and $-\mathrm{V},-\mathrm{I}$ is in inverting mode. A positive converter will provide a positive current, and a negative converter will provide a negative current to the load.

Performance Comparison Modeling Between Single-phase Cycloconverters and Three-phase Cycloconverters Using Matlab Simulink Tools (Setiyono) 
Fig. 4(a) is three three-phase voltage waves $V a, V b, V c$ frequency $50 \mathrm{~Hz}$, and the output wave dividing three input frequencies $\left(f_{o}=\frac{1}{3} f_{\text {in }}\right.$ is $16.67 \mathrm{~Hz}$ ). The switch converter $\mathrm{P}$ and $\mathrm{N}$ are switched on at $\alpha=0^{0}$ for the $\mathrm{P}$ converter and $\alpha=\pi+\alpha$, for the $\mathrm{N}$ converter. The first three cycles of the $\mathrm{P}$ converter convert the positive period, and the first three cycles of the $\mathrm{N}$ converter convert the first negative cycle. Fig. 4(b) is a voltage waveform of the frequency dividing three expressed in red line waves. The average output voltage can be obtained [13] as

$$
\begin{gathered}
V_{d c}=\frac{3}{\pi} \int_{\pi / 6+\alpha}^{\pi / 2+\alpha} v_{a b} d(\omega t)=\frac{3}{\pi} \int_{\pi / 6+\alpha}^{\pi / 2+\alpha} \sqrt{3} V_{m} \sin \left(\omega t+\frac{\pi}{6}\right) d(\omega t) \\
V_{d c}=\frac{3 \sqrt{3} V_{m}}{\pi} \cos \alpha
\end{gathered}
$$

The output voltage rms value can be obtained by

$$
\begin{gathered}
V_{r m s}=\left[\frac{3}{\pi} \int_{\pi / 6+\alpha}^{\pi / 2+\alpha} 3 V_{m}^{2} \sin ^{2}\left(\omega t+\frac{\pi}{6}\right) d(\omega t)\right]^{\frac{1}{2}} \\
V_{r m s}=\sqrt{3} V_{m}\left(\frac{1}{2}+\frac{3 \sqrt{3}}{4 \pi} \cos 2 \alpha\right)^{\frac{1}{2}}
\end{gathered}
$$

(a)

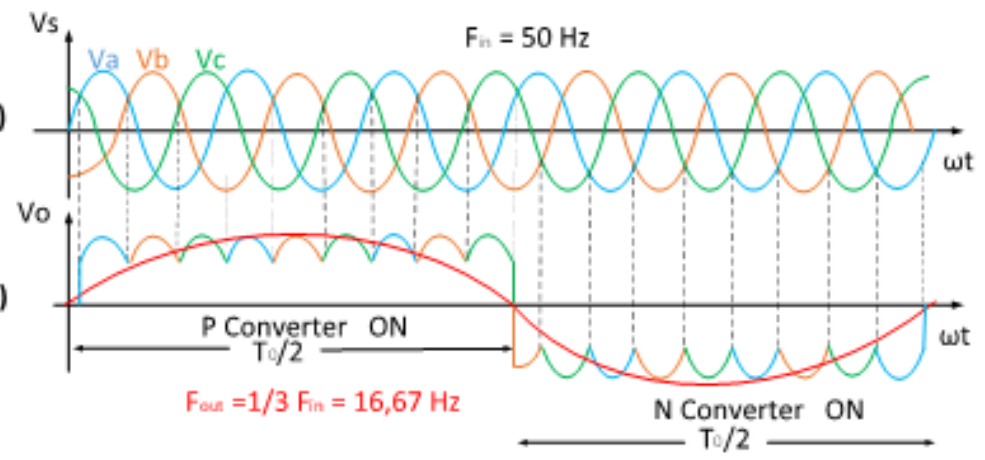

Fig. 4. Output Voltage Waveform of Three-Phase Cycloconverter Divider with Thyristor

\subsection{Total Harmonic Distortion (THD}

Total Harmonic Distortion (THD) is the root mean square (RMS) value of the harmonic content expressed as a percentage of the fundamental component. THD is expressed as

$$
T H D=\frac{\sqrt{\sum_{n=2}^{N} X_{n}^{2}}}{X_{1}}
$$

Where $X_{n}$ is the RMS of a certain waveform at harmonic order $n, N$ is the supreme harmonic order and $X_{1}$ is the fundamental RMS value of the same waveform [14].

\section{METHOD}

Fig. 5 is a research method and system workflow. This study compares the performance of a single-phase cycloconverter and a three-phase cycloconverter. The first is to design a single-phase cycloconverter and threephase cyclo converter. The electronic devices used in both circuits are diodes and thyristors. Then the two circuits were modeled using the Matlab Simulink tool. The parameters to be measured are the input voltage waveform, frequency of output voltage wave, RMS, and THD values for each circuit. Simulation testing of each cycloconverter circuit uses two different semiconductor devices to find the character and performance of the circuit against changes in the output voltage and the resulting frequency. Results of the observations were then analyzed to obtain the character and performance of each cycloconverter circuit. 


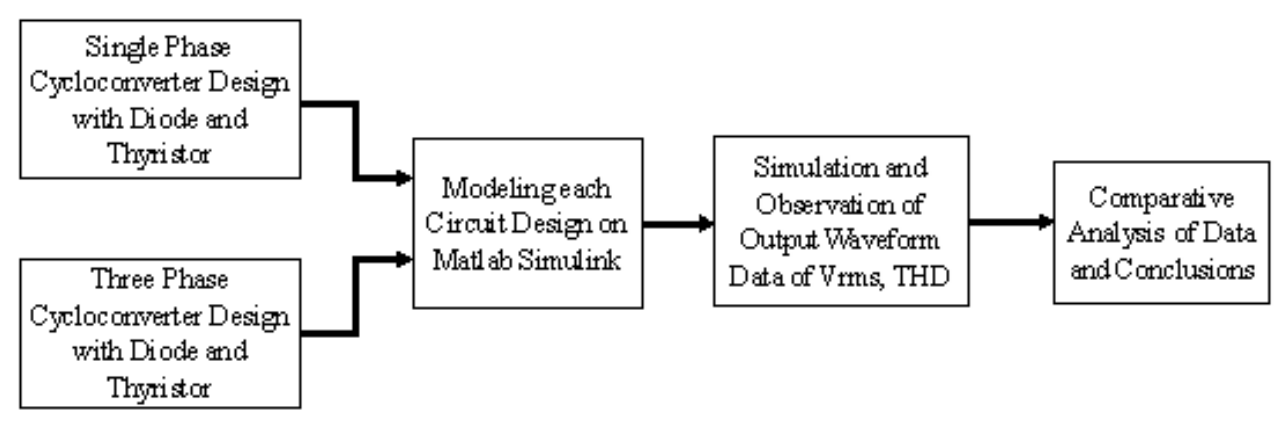

Fig. 5. Research Methods and Workflow Systems

\subsection{Modeling Single-Phase Cycloconverter using Diode and Thyristor Devices}

Fig. 6 shows a single-phase cycloconverter circuit modeling using a diode with $\mathrm{R}=100 \mathrm{ohm}$, or loads with a power factor of one, the source voltage of each converter is $100 \mathrm{Vpp}$ frequency of $50 \mathrm{~Hz}$.

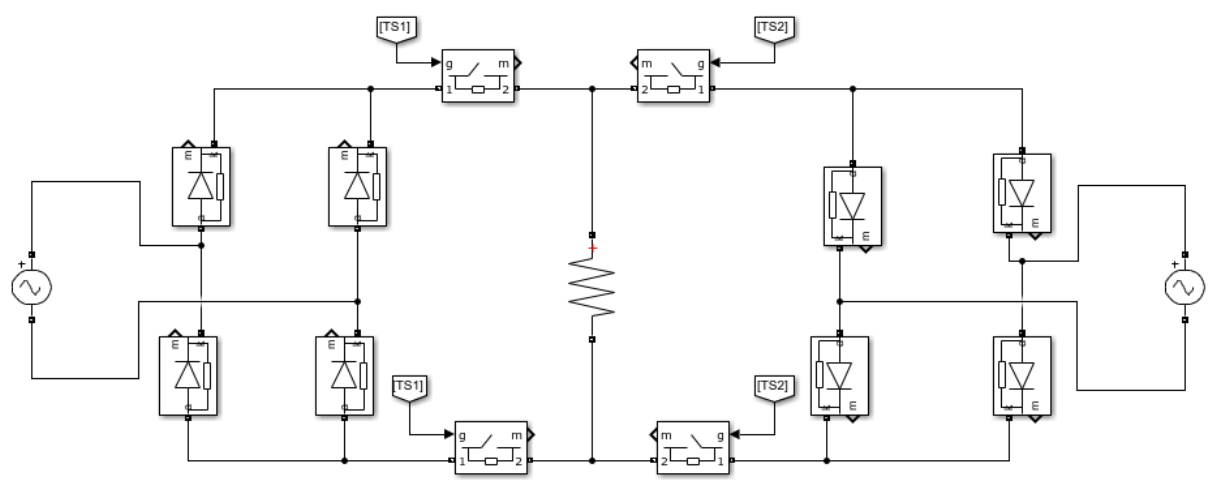

Fig. 6. Modeling of Single-phase Diode Cycloconverter

The performance of the $\mathrm{P}$ side converter switches and is controlled by two switches located on the right side, which are turned on by TS1. In comparison, the performance of the N converter is controlled by two switches located on the left side of the N converter and turned on by TS2. TS1 and TS2 are firing pulses that have the same pattern but have a phase difference of $180^{\circ}$.

Fig. 7 shows a single-phase cycloconverter circuit modeling using a thyristor device with $\mathrm{R}$ load 100 ohm, Vin $100 \mathrm{Vpp} 50 \mathrm{~Hz}$ each converter. In contrast to a single-phase cycloconverter diodes, output parameters RMS, THD, and frequency of the output thyristor cycloconverter can be controlled by two methods, namely setting pulse width of switch converter P and convertor N and pulse width setting TS1 and TS2. This circuit requires four firing pulses $\mathrm{S} 1, \mathrm{~S} 2, \mathrm{~S} 3, \mathrm{~S} 4$, four pulses firing converter $\mathrm{P}$, and four firing pulses $\mathrm{N}$ converter. The advantages of this cycloconverter are more complex in setting the output voltage parameters, but on the other hand, the use of this converter requires a more complicated circuit, and of course, there is a waste of power consumed by this circuit.

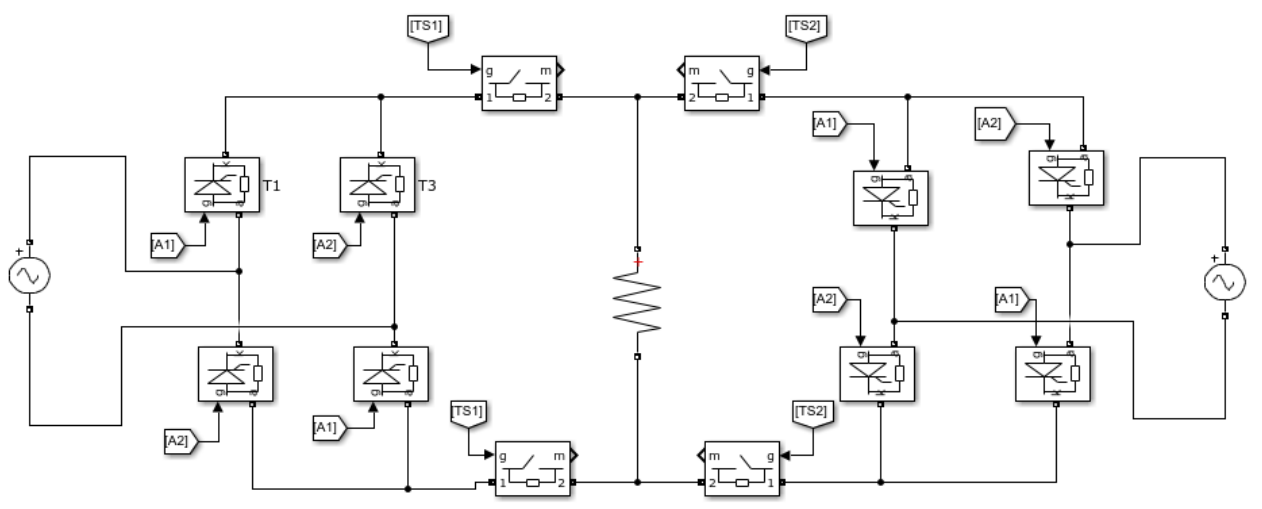

Fig. 7. Modeling Single Phase of Thyristor Cycloconverter

Performance Comparison Modeling Between Single-phase Cycloconverters and Three-phase Cycloconverters Using Matlab Simulink Tools (Setiyono) 


\subsection{Three-Phase Cycloconverter Modeling Using Diode and Thyristor Devices}

The next research is by modeling a three-phase cycloconverter using a diode and thyristor device. This circuit is arranged using one positive converter $(\mathrm{P})$, six diodes or thyristor, and one negative converter $(\mathrm{N})$, three pairs of diodes or thyristor as well. The output voltage is taken from the resistor load of $100 \mathrm{ohms}$. Fig. 8 shows a three-phase cycloconverter circuit using a diode model. A three-phase voltage power system (173 $\mathrm{V}_{\mathrm{L}-\mathrm{L}}, 50 \mathrm{~Hz}$ ) supplies to the $\mathrm{P}$ converter and $\mathrm{N}$ converter. The input frequency divider is carried out by switches S1, S2, S3, and S4 with the same working principle as the single-phase cycloconverter frequency divider.

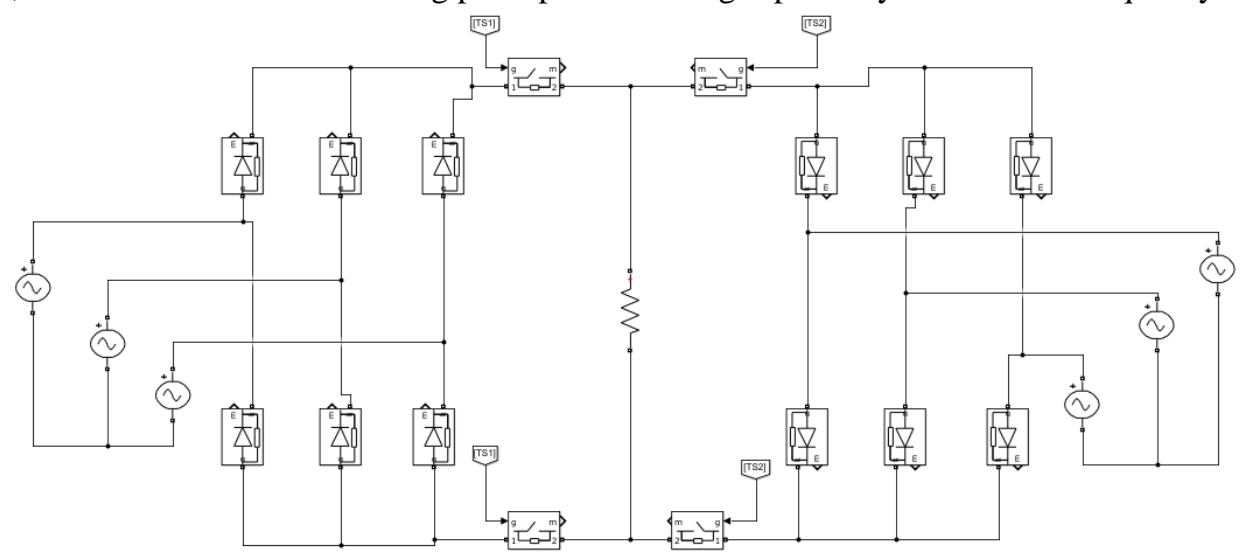

Fig. 8. Modeling Three Phase Cycloconverter with Diode

Fig. 9 is a three-phase cycloconverter with thyristor modeling, but this model circuit requires a gating pulses generator for 12 switches, so the circuit is more complex and complicated. The converter switch is designed in $120^{\circ}$ conduction mode, and the adjustment of the output wave frequency is carried out by the pulse width control switches S1, S2, S3, and S4, namely TS1 and TS2.

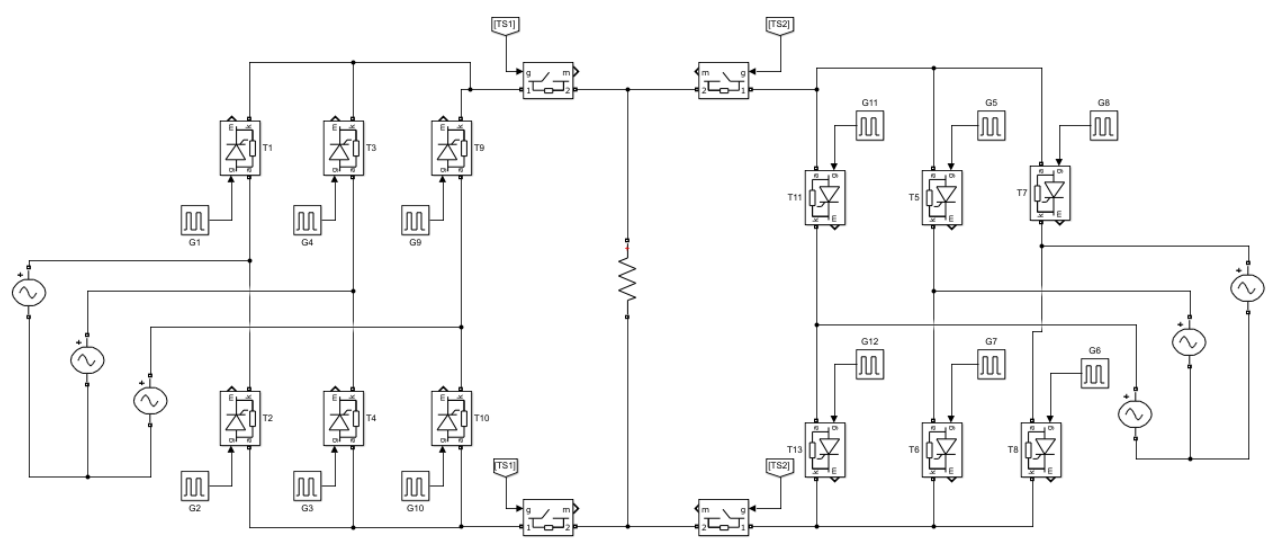

Fig. 9. Three Phase Cycloconverter with Thyristor

\section{RESULTS AND DISCUSSION}

\subsection{Single Phase Cycloconverter with Diode Simulation Result}

Fig. 10(a) is a 100volt sinusoidal input voltage wave frequency of $50 \mathrm{~Hz}$. Fig. 10(b) is the triggering pulse for switches S1 and S2, while Fig. 10(c) is the triggering pattern for switches S3 and S4. Fig. 10(d) is a $25 \mathrm{~Hz}$ frequency output voltage waveform, or in other words, the cycloconverter is designed to divide two input voltage frequencies. It appears that for one period, the input waveform generates a half-period voltage of the output wave. In each cycle of the output wave, there are two half-wave patterns of the input voltage. This is the result of rectifying the $\mathrm{P}$ converter and $\mathrm{N}$ converter switch bridge. The output voltage frequency is equal to triggering pulse frequency $\mathrm{T}_{\mathrm{S} 1}$ and $\mathrm{T}_{\mathrm{S} 2}$. The bandwidth of the firing pulse period $\left(\mathrm{T}_{\mathrm{S} 1}\right.$ and $\left.\mathrm{T}_{\mathrm{S} 2}\right)$ determines the parameters of the cycloconverter circuit output waveform parameters, as shown in Table 1. The value of Tsn can be calculated using

$$
T s n=\frac{1}{f n}
$$



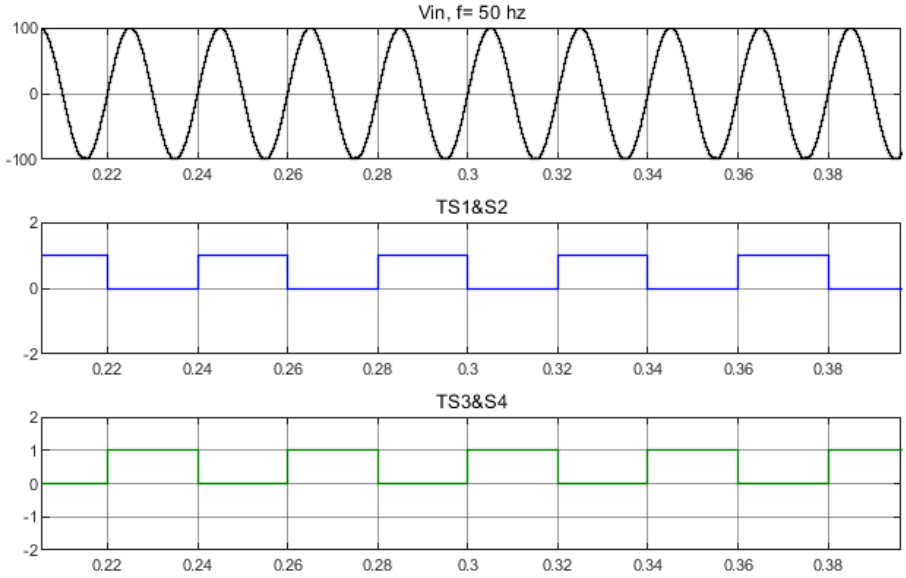

Vout, Fout $=$ F in $/ 2=25 \mathrm{~Hz}$

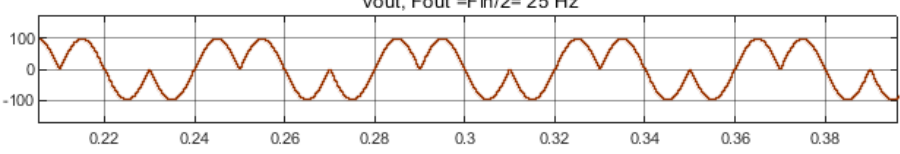

Fig. 10. Simulated Data of Single-Phase Diode Cycloconverter Divider Waveform

Eq. (3), (6), and (7) is to calculate the values of $\mathrm{T}_{\mathrm{SN}}$, THD, and Vrms. Table 1 results data simulation for the frequency divider from $f$ to $\frac{f}{10}$ shows that at the fundamental frequency $(50 \mathrm{~Hz})$, this cycloconverter has a large RMS value with a low THD index. The pulse width settings of $\mathrm{T}_{\mathrm{S} 1}$ and $\mathrm{T}_{\mathrm{S} 2}$ increase by $0.02 \mathrm{~s}$ for each of the previous half frequencies. The THD index increases when the frequency decreases. The THD index increases when the frequency decreases. This is due to a change in the waveform of the output voltage with a lower frequency.

Table 1. RMS, $\mathrm{T}_{\mathrm{SN}}$, and THD Values on a Single-Phase Diode Cycloconverter at Each Fout Vin $=100 \mathrm{Vpp}$, Fin $50 \mathrm{~Hz}$

\begin{tabular}{ccccc}
\hline $\mathrm{n}$ & Fout $=$ fin $/ \mathrm{n}(\mathrm{Hz})$ & $\mathrm{T}_{\mathrm{S} 1} \& \mathrm{~T}_{\mathrm{S} 2}$ & THD $(\%)$ & Vout, RMS $(\mathrm{V})$ \\
\hline 1 & 50 & 0.02 & 1.79 & 69.25 \\
2 & 25 & 0.04 & 63.1 & 58.56 \\
3 & 16.66 & 0.06 & 68.98 & 56.99 \\
4 & 12.5 & 0.08 & 70.84 & 56.5 \\
5 & 10 & 0.10 & 71.72 & 56.27 \\
6 & 8.33 & 0.12 & 72.2 & 56.14 \\
7 & 7.142 & 0.14 & 72.4 & 56.06 \\
8 & 6.25 & 0.16 & 72.66 & 56.02 \\
9 & 5.555 & 0.18 & 72.77 & 55.98 \\
10 & 5 & 0.2 & 72.88 & 55.96 \\
\hline
\end{tabular}

Fig. 11 shows the THD index value of the two dividers of $63.10 \%$. Dividing the cycloconverter causes the voltage wave to change from sinusoidal to a distorted sinusoidal waveform. In two dividers, this means that the basic frequency is $16,667 \mathrm{~Hz}$. The magnitude of the frequency of the disturbance occurs in the 3rd, 5th, 7th order or at frequencies $75 \mathrm{~Hz}, 125 \mathrm{~Hz}, 175$, and so on. So it can be said that the noise frequency signal occurs in an odd order. Frequencies above the 9th order are so small that they can be ignored.

\subsection{Single Phase Cycloconverter with Thyristor Simulation Result}

Fig. 12 shows the change in the input wave that is divided in half by the cyclocnverter circuit into a distorted sine wave. The pattern and pulse width of TS1 and TS2 have an effect on the output frequency. In the simulation design, the TS1 and TS2 are set with a duty cycle of 50\%. TS1 and TS2 have the same frequency but have different phases of $180^{\circ}$. The output voltage waveform is also influenced by the switching on of the $\mathrm{P}$ converter and the $\mathrm{N}$ converter. Positive (Converter $\mathrm{P}$ ) and Negative (Converter $\mathrm{N}$ ) cycle output waves there are two half-wave streams. The positive cycle is activated at $\alpha=30^{\circ}$ and the negative cycle is activated at $\alpha=210^{0}$. 


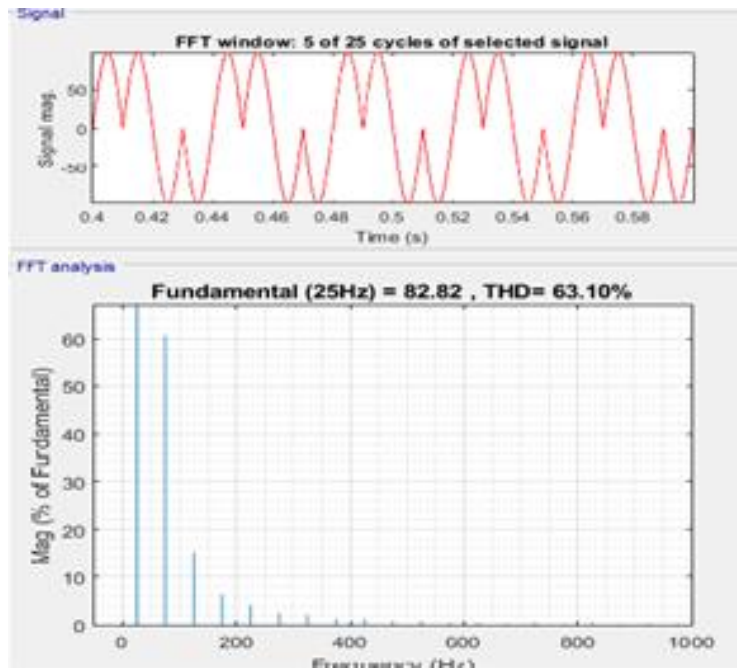

Fig. 11. THD index on a single phase cycloconverter divider diode
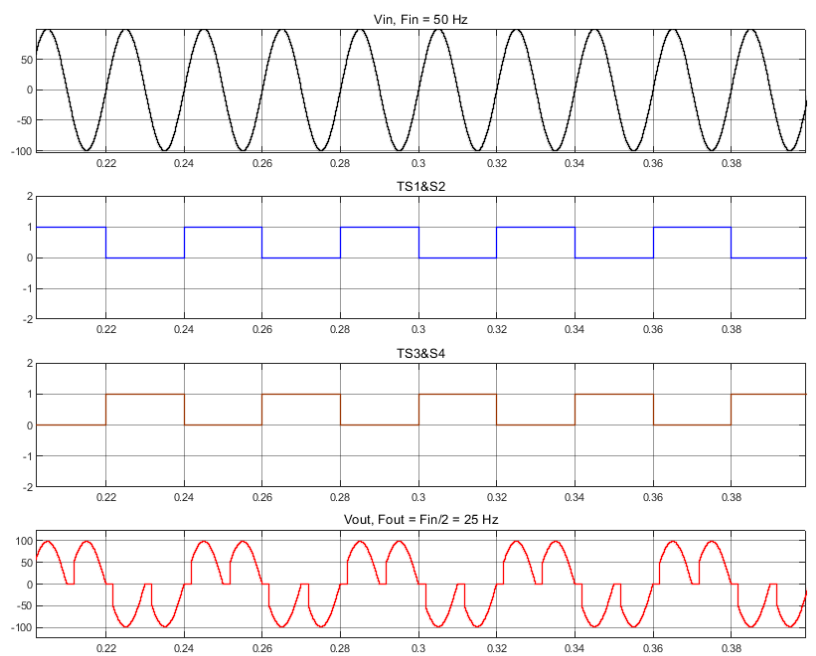

Fig. 12. Simulated Data of Single-Phase Thyristor Cycloconverter 2-Divider Waveform

Eq. (3), (6) and (7) is to calculate of THD and Vrms value. Table 2 shows the test results of the frequency divider of the $f$ to $\frac{f}{10}$ cycloconverter with thyristor. When the $\mathrm{P}$ converter and $\mathrm{N}$ converter are ignited at $30^{\circ}$ and $210^{\circ}$, the THD value at the base frequency of $50 \mathrm{~Hz}$ is $67.33 \%$. The THD index increases at lower frequencies and changes relatively constant. Likewise, the Vrms value will decrease according to the change in the frequency of the output voltage.

Table 2. RMS, $\mathrm{T}_{\mathrm{SN}}$, and THD Values on a Single-Phase Thyristor Cycloconverter at each Fout Vin=100 Vpp, Fin $50 \mathrm{~Hz}$

\begin{tabular}{cccccc}
\hline $\mathrm{n}$ & Fout $=$ fin $/ \mathrm{n}(\mathrm{Hz})$ & TS1, TS2 & THD $(\%)$ & Vout, RMS $(\mathrm{V})$ & Firing angle T1-T4, T5-T8 \\
\hline 1 & 50 & 0.02 & 16.05 & 67.33 & $30^{0}, 210^{0}$ \\
2 & 25 & 0.04 & 72.94 & 55.09 & $30^{0}, 210^{0}$ \\
3 & 16.66 & 0.06 & 79.76 & 53.3 & $30^{0}, 210^{0}$ \\
4 & 12.5 & 0.08 & 81.96 & 52.74 & $30^{0}, 210^{0}$ \\
5 & 10 & 0.10 & 83 & 52.47 & $30^{0}, 210^{0}$ \\
6 & 8.33 & 0.12 & 83.63 & 52.3 & $30^{0}, 210^{0}$ \\
7 & 7.142 & 0.14 & 83.9 & 52.32 & $30^{0}, 210^{0}$ \\
8 & 6.25 & 0.16 & 84.11 & 52.19 & $30^{0}, 210^{0}$ \\
9 & 5.555 & 0.18 & 84.36 & 52.10 & $30^{0}, 210^{0}$ \\
10 & 5 & 0.2 & 84.37 & 52.12 & $30^{0}, 210^{0}$ \\
\hline
\end{tabular}

Performance Comparison Modeling Between Single-phase Cycloconverters and Three-phase Cycloconverters Using Matlab Simulink Tools (Setiyono) 
Fig. 13 shows the THD index of 3- thyristor cycloconverter divider of $79.70 \%$. There are three half-wave pulses in the positive cycle and the negative cycle, which are activated at each firing angle. This process causes the output wave to change from a pure sinusoid to a distorted sinusoid. The frequency of the disturbance is in the odd order $3,5,7,9,11$ or at a frequency of $75 \mathrm{~Hz}, 125 \mathrm{~Hz}, 175 \mathrm{~Hz}$. For frequencies above $200 \mathrm{~Hz}$, the effect is too small, so it can be neglected.

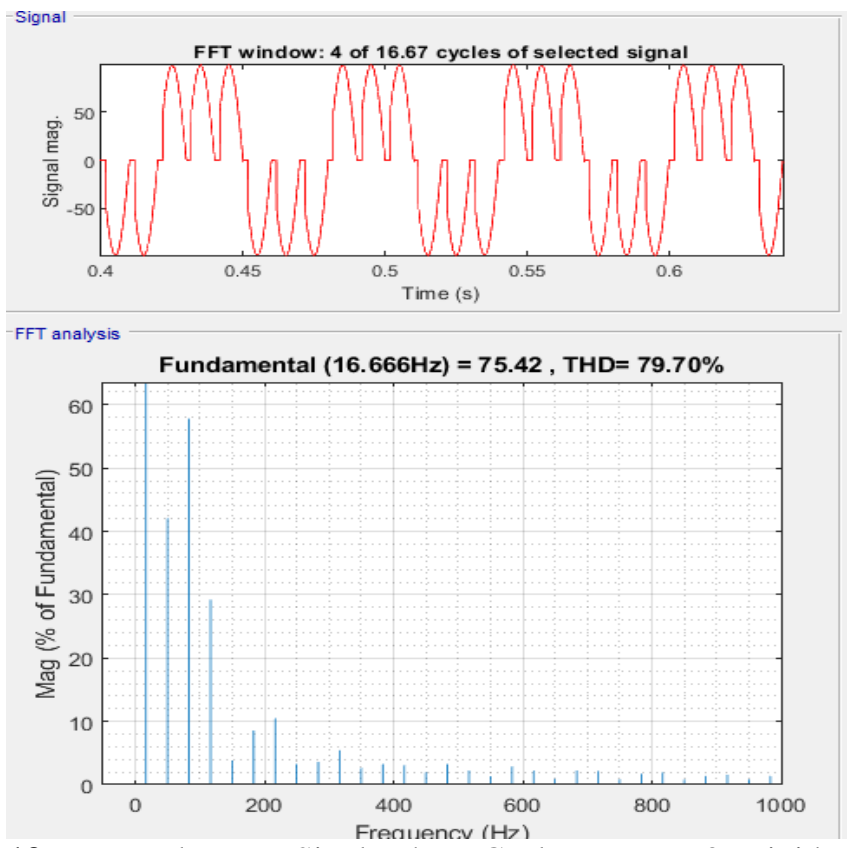

Fig. 13. THD Index on a Single Phase Cycloconverter 3- Divider Thyristor

\subsection{Three Phase Cycloconverter with Diode Simulation Result}

The following is one of the data simulation results shown in Fig. 14. Fig.14(a) is a simulation of a 100 Vpp $50 \mathrm{~Hz}$ three-phase voltage system. Fig. 14(b) and Fig. 14(c) are the trigger pulses TS1 and TS2, which are used to turn on switches S1, S2, and S2, S4 divides 4 cycloconverters. The magnitude trigger pulse is $1 \mathrm{~V}$ with a period is set at $\mathrm{T}_{\mathrm{S}}=0.08 \mathrm{~s}$ so that the output frequency is $12.5 \mathrm{~Hz}$. The output voltage with an amplitude of $147 \mathrm{~V}$ is similar to an alternating square wave but has ripples in both cycles. The number of ripples is 12 per cycle.
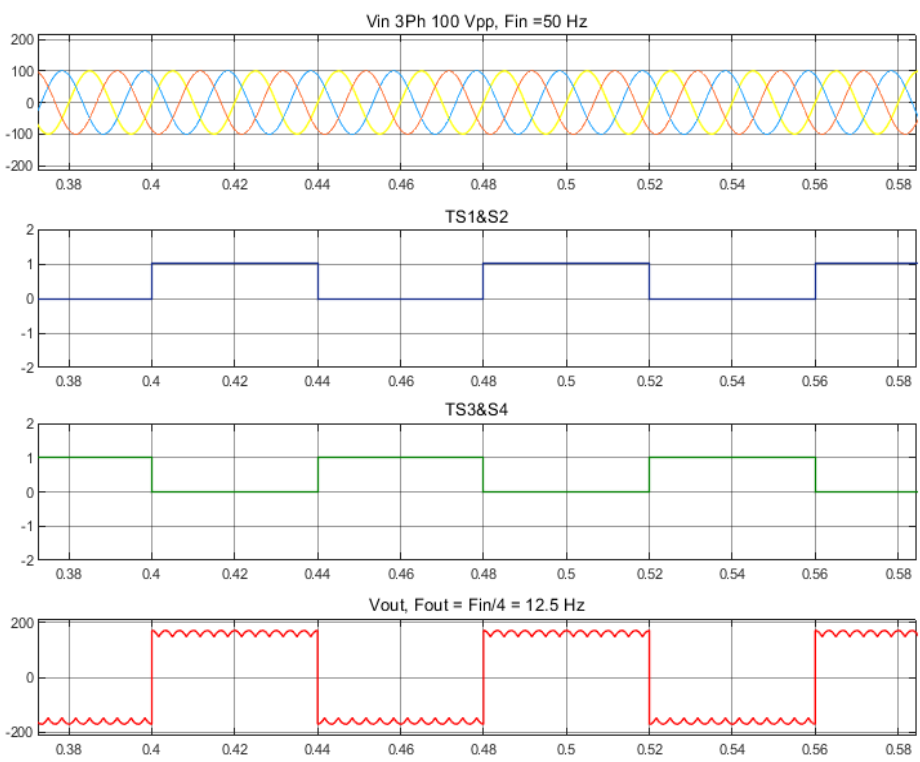

Fig. 14. Simulated Data of Three-Phase Diode Cycloconverter 4-Divider Waveform 
Table 3 explains that by adjusting the pulse widths of the switches S1, S2, S3, and S4, the RMS and THD values are obtained, which relatively the same or, in other words, the THD and RMS parameter changes on three-phase cycloconverter are relatively small. At frequencies below $1 / 2$ Fin, the average THD index value is $48.44 \%$. Meanwhile, the RMS voltage value is relatively constant (147.3V).

Table 3. Setting a Pulse Width for RMS and THD values

\begin{tabular}{ccccc}
\hline $\mathrm{n}$ & Fout $=$ fin $/ \mathrm{n}(\mathrm{Hz})$ & $\mathrm{T}_{\mathrm{S} 1} \& \mathrm{~T}_{\mathrm{S} 2}$ & THD $(\%)$ & Vout, RMS $(\mathrm{V})$ \\
\hline 1 & 50 & 0.02 & 47.90 & 146.9 \\
2 & 25 & 0.04 & 48.21 & 147.3 \\
3 & 16.66 & 0.06 & 48.29 & 147.3 \\
4 & 12.5 & 0.08 & 48.35 & 147.3 \\
5 & 10 & 0.10 & 48.40 & 147.3 \\
6 & 8.33 & 0.12 & 48.42 & 147.3 \\
7 & 7.142 & 0.14 & 48.44 & 147.3 \\
8 & 6.25 & 0.16 & 48.46 & 147.3 \\
9 & 5.555 & 0.18 & 48.47 & 147.3 \\
10 & 5 & 0.2 & 48.48 & 147.3 \\
\hline
\end{tabular}

Fig. 15 shows the THD index value of the three-phase thyristor 4 cycloconverter divider of $48.35 \%$. Oddorder frequencies have an effect on the output wave format. Basically, a square wave is a sinusoidal wave with a certain frequency plus a sine wave with an integer multiple of the fundamental frequency. In this simulation, the results are in the form of a square wave, so according to Fig. 15, the wave signal that causes a change in shape is a wave signal at odd-order frequencies of $125 \mathrm{~Hz}, 175 \mathrm{~Hz}, 225 \mathrm{~Hz}$, etc.
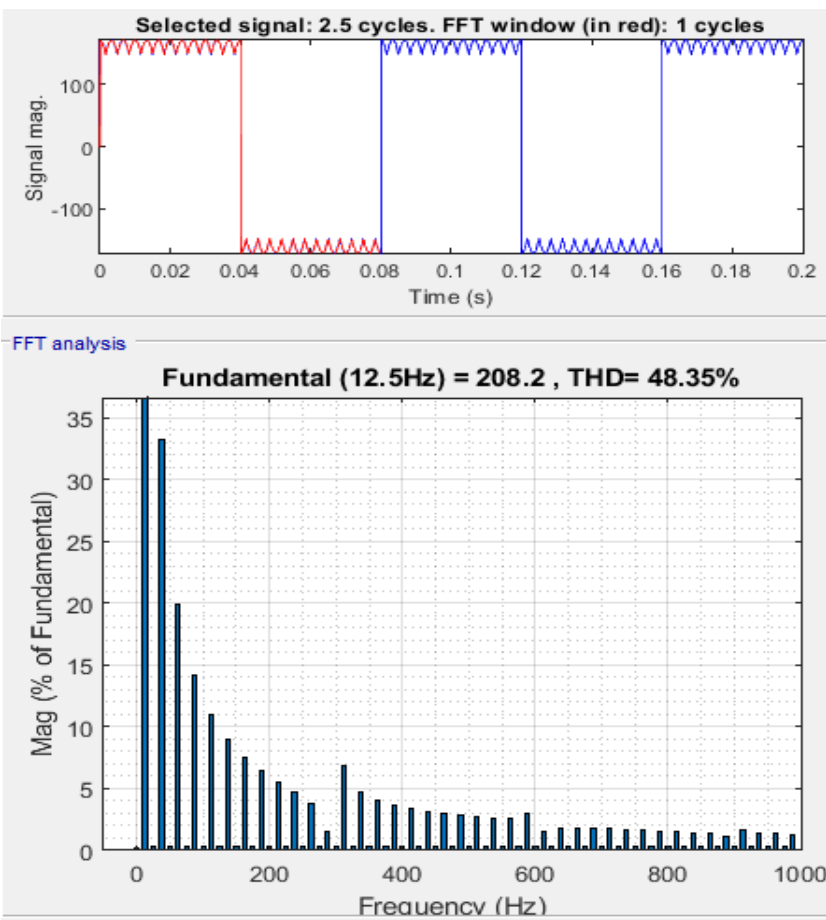

Fig. 15. THD Index Value of Divider 4 on 3-phase Diode Cycloconverter

\subsection{Three Phase Cycloconverter with Thyristor Simulation Result}

Fig. 16 is the simulation result of a three-phase cycloconverter circuit using a thyristor device. Thyristor switched on at $120^{\circ}$ operation mode. The $\mathrm{P}$ converter is turned on at the ignition node $30^{\circ}$ so that the $\mathrm{N}$ converter is switched on at the firing node $210^{\circ}$. Fig. 16(a) is a three-phase voltage source simulation wave with a magnitude of $100 \mathrm{Vpp}$ with a frequency of $50 \mathrm{~Hz}$. Fig. 16(b) and Fig. 16(c) are trigger pulses with a phase difference of $180^{\circ}$ for switches S1 S2 and S3 S4, which are shifted as far as $30^{\circ}$. Figure 16d describes the output voltage wave pattern of the three-phase thyristor 4 cycloconverter divider. This voltage wave is actually the same as the voltage wave pattern in the cycloconverter using a diode, but there are several instantaneous cycles 
that are cut off due to control by the $\mathrm{P}$ converter thyristor and $\mathrm{N}$ converter so that the resulting waveform changes with a different pattern.

Table 4 explains that changes in pulse widths of TS1 and TS2 at each $\mathrm{f} / \mathrm{n}$ result in non-linear changes in THD index values and Vrms. This is influenced by the output voltage waveform factor due to controlling the $\mathrm{P}$ converter switch and the $\mathrm{N}$ converter when the $\mathrm{P}$ converter and the $\mathrm{N}$ converter are firied $\alpha=30^{\circ}$. The highest THD index value is achieved when the system is operated on divider 7, and the lowest is in divider 1 . While the largest Vrms value is in divider 1, and the lowest is in divider 2.
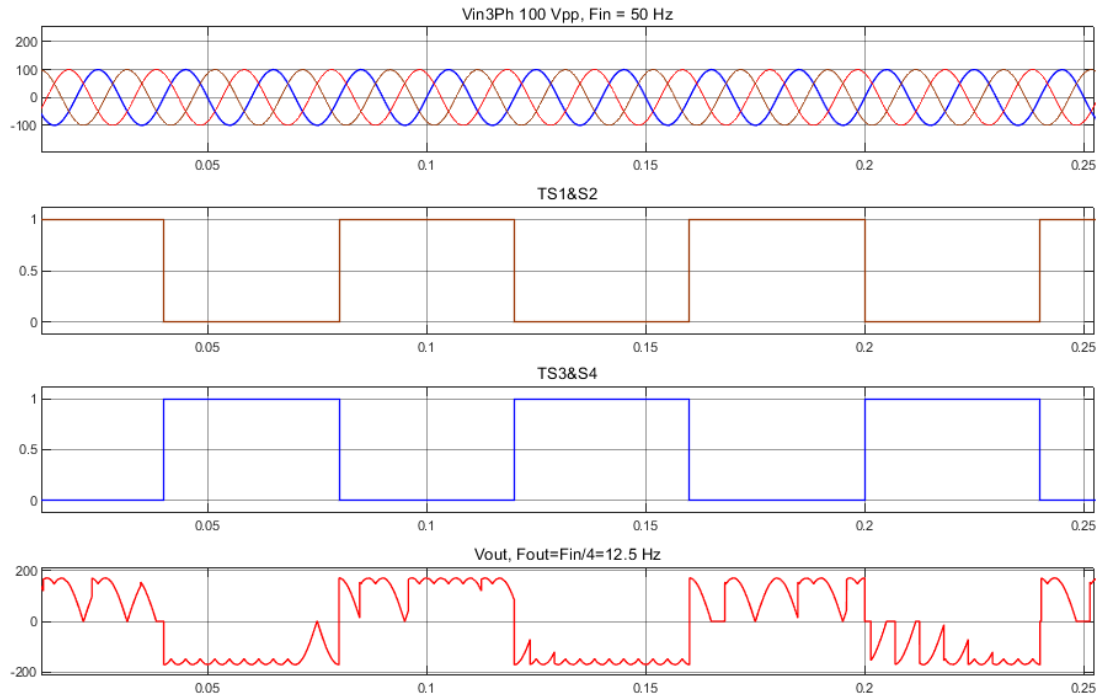

Fig. 16. Simulated Data of Three-Phase Thyristor Cycloconverter 4-Divider Waveform

Table 4. The Effect of Changes in the trigger Pulse Width on The Output of Vrms and THD Index Value

\begin{tabular}{ccccc}
$\mathrm{n}$ & Fout $=$ fin $/ \mathrm{n}(\mathrm{Hz})$ & $\mathrm{T}_{\mathrm{S} 1} \& \mathrm{~T}_{\mathrm{S} 2}$ & THD $(\%)$ & Vout RMS $(\mathrm{V})$ \\
\hline 1 & 50 & 0.02 & 58.44 & 92.41 \\
2 & 25 & 0.04 & 60.23 & 28.15 \\
3 & 16.66 & 0.06 & 64.40 & 10.84 \\
4 & 12.5 & 0.08 & 48.24 & 10.71 \\
5 & 10 & 0.10 & 64.72 & 63.28 \\
6 & 8.33 & 0.12 & 88.11 & 28.15 \\
7 & 7.142 & 0.14 & 92.10 & 10.65 \\
8 & 6.25 & 0.16 & 72.28 & 10.72 \\
9 & 5.555 & 0.18 & 63.43 & 10.87 \\
10 & 5 & 0.2 & 63.37 & 63.34 \\
\hline
\end{tabular}

Fig. 17 explains the THD index divider 2 value of $60.23 \%$. Interfering wave frequencies are in an odd order, especially at frequencies below $200 \mathrm{~Hz}$. At signal interference waves with frequencies above $200 \mathrm{~Hz}$, the magnitude value is getting smaller and can be ignored.

\section{CONCLUSION}

Cycloconverter diodes, both single-phase and three-phase systems, have better parameters for the THD and Vrms index values than cycloconverter thyristors. This is due to the waveform factor generated by the two cycloconverters. The output voltage waveform is close to the square waveform, but there are ripple waves in positive and negative cycles. The number of ripple waves is equal to the $n-t h$ divider of the cycloconverter. An interference wave signal that is in odd order causes a non-sinusoid output wave. The nth divider of cycloconverter is controlled by the pulse width of the ignition switch $\mathrm{p}$ converter and converter $\mathrm{N}$. Diode, and Thyristor cycloconverter produces ten output voltage frequency settings. This setting value is narrow, so that this system needs to be developed to get a wide output voltage frequency setting.

\section{Acknowledgments}

Thanks to Gunadarma University for support so that this research can be completed on time.

Performance Comparison Modeling Between Single-phase Cycloconverters and Three-phase Cycloconverters Using Matlab Simulink Tools (Setiyono) 

Vol. 7, No. 2, August 2021, pp. 217-229
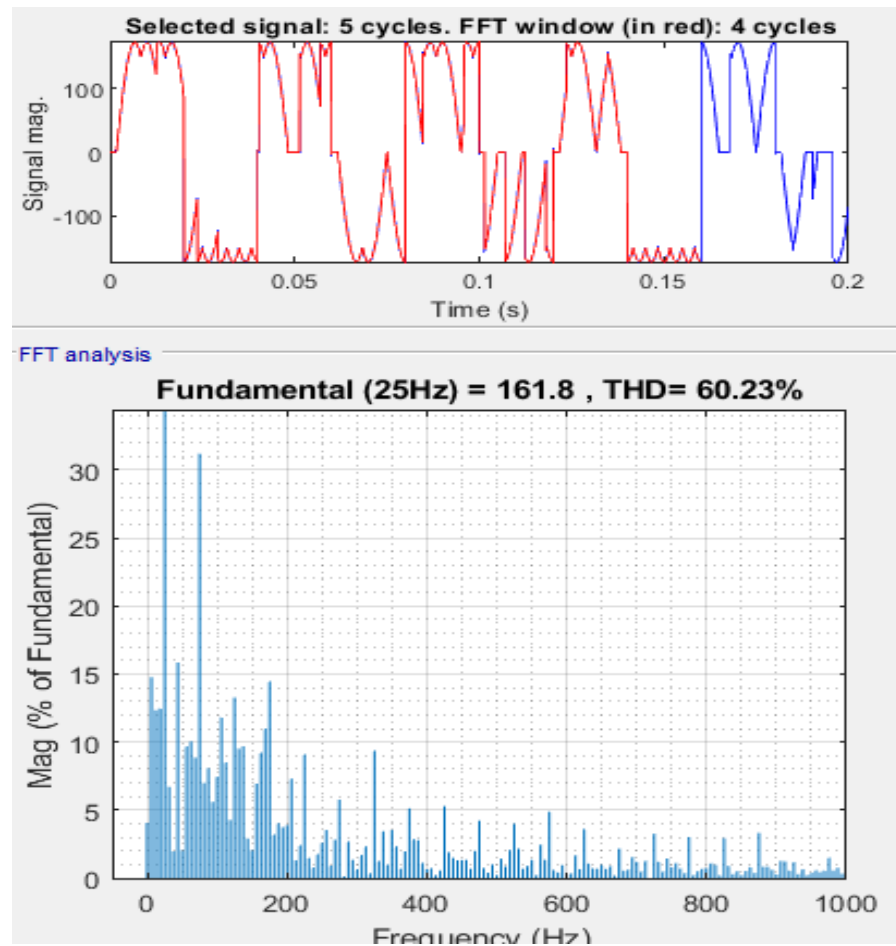

Fig. 17. THD Index Value of Divider 2 on Three-phase Thyristor Cycloconverter

\section{REFERENCES}

[1] K. Kumar, L. N. Sharma, A. Naggarwal, H. Sharma, M. Mahato, and H. Kaur, "Designing of Thyristor Based Cycloconverter to Control Induction Motor," vol. 6, no. 11, pp. 29-32, 2019. http://ijiset.com/vol6/v6s11/IJISET_V6_I11_04.pdf

[2] A. A. Nyein, "Analysis of Cycloconverter Fed Induction Motor Drive," Int. J. Trend Sci. Res. Dev., vol. 3, no. 1, pp. 569-574, 2018. https://doi.org/10.31142/ijtsrd19041

[3] V. Patel, D. Makawana, V. Rangpara, J. Zala, and P. Bank, “AC to AC Step Down Cycloconverter,” Int. Res. J. Eng. Technol., vol. 4, no. 3, pp. 3-8, 2017. https://www.irjet.net/archives/V4/i3/IRJET-V4I3362.pdf

[4] A. Alias, "Modeling and simulation of single phase inverter with PWM using MATLAB/Simulink," Thesis, Universiti Malysia Pahang, 2007. http://umpir.ump.edu.my/568

[5] S. Syed, P. K. Injam and K. Silvacus, "Parameter Unit Mode and External Mode Based Speed Control of Three Phase Induction Motor Using Variable Frequency Drive," 2020 International Conference on Renewable Energy Integration into Smart Grids: A Multidisciplinary Approach to Technology Modelling and Simulation (ICREISG), 2020, pp. 99104. https://doi.org/10.1109/ICREISG49226.2020.9174419

[6] Ayebatonye Marttyns Epemu, Kingsley Okeoghene Enalume, Speed Control of a Single Phase Induction Motor Using Step-down Cycloconverter, International Journal of Industrial and Manufacturing Systems Engineering. Vol. 3, No. 1, pp. 6-10, 2018. https://doi.org/10.11648/j.ijimse.20180301.12

[7] A. M. Epemu and K. O. Enalume, "Speed Control of a Single Phase Induction Motor Using Step-down Cycloconverter, International Journal of Industrial and Manufacturing Systems Engineering. Vol. 3, No. 1, 2018, pp. 6-10. https://doi.org/10.11648/j.ijimse.20180301.12

[8] B. Patil, R. Aute, P. Mhaske and N. Patil, "Survey on Thyristor Using Cyclocnverter," International Research Journal of Engineering and Technology, vol. 3, no. 4, p. 514, 2016. https://www.irjet.net/archives/V3/i4/IRJET-V3I4105.pdf

[9] J. S. Vinodhini, R. S. R. Babu, and J. A. Glenn, "Single phase to single phase step-down cycloconverter for electric traction applications," Int. Conf. Electr. Electron. Optim. Tech. ICEEOT 2016, vol. 11, no. 4, pp. 4914-4916, 2016. https://doi.org/10.1109/ICEEOT.2016.7755387

[10] Y. P. S. K. Gowda, G. Hema, S. D. Prasad, and V. Vilasitha, "Performance and Speed Control of Cycloconverter Fed Split Phase Induction Motor," pp. 1142-1146, 2016. https://www.irjet.net/archives/V3/i9/IRJET-V3I9209.pdf

[11] D. Kumar, "Performance Analysis of Three-Phase Induction Motor with AC Direct and VFD," IOP Conf. Ser. Mater. Sci. Eng., vol. 331, no. 1, 2018. https://doi.org/10.1088/1757-899X/331/1/012025

[12] R. Prakash, S. Nyekha, P. Sahu, P. D. Tiwari, and M. E. Emd, "SPMC as Single Phase to Single Phase Cycloconverter with SPWM using MATLAB / Simulink," vol. 1, no. 10, pp. 59-67, 2016. https://www.ijsdr.org/viewpaperforall.php?paper=IJSDR1610011

[13] M. H. RASHID, Power Electronic: Circuits, Devices, And Application, 2th ed. Prentice Hall Inc, 1999.

[14] L. Alhmoud, "THD reduction using shunt active power filter: A real case study," Univers. J. Electr. Electron. Eng., vol. 6, no. 4, pp. 259-264, 2019. https://doi.org/10.13189/ujeee.2019.060407 
[15] R. Martinek, J. Rzidky, R. Jaros, P. Bilik, and M. Ladrova, "Least Mean Squares and Recursive Least Squares Algorithms for Total Harmonic Distortion Reduction Using Shunt Active Power Filter Control," Energies, vol. 12, no. 8, p. 1545, Apr. 2019. http://dx.doi.org/10.3390/en12081545

\section{BIOGRAPHY OF AUTHORS}

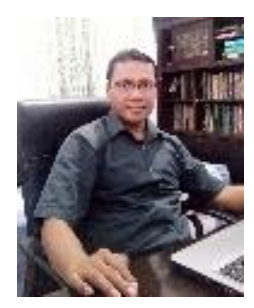

Dr. Setiyono, Head of Electrical Engineering Laboratory of Gunadarma University, Bachelor of Electrical Engineering, Master of Electrical Engineering, Doctor of Information Technology, Gunadarma University Information. Deep research on energy, control, and power systems.

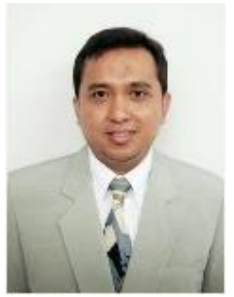

Bambang Dwinanto is a secretariat staff of Rectorat bachelor the Electrical Engineering University of Muhammadiyah Jakarta, Master of Electrical Engineering, Gunadarma University Jakarta, concern in electrical engineering. 